\title{
Teaching Reading Narrative Text through Inking Your Thinking Strategy
}

\author{
Siti Hadiyati Rohmana ${ }^{1)}$, Indawan Syahri ${ }^{2)}$, Masagus Sulaiman ${ }^{3)}$ \\ ${ }^{1}$ Universitas Muhammadiyah Palembang \\ E-mail: Rohmanasitihadiyati@gmail.com \\ ${ }^{2}$ Universitas Muhammadiyah Palembang \\ E-mail: indawansyahri_ump@yahoo.co.id \\ ${ }^{3}$ Universitas Muhammadiyah Palembang \\ E-mail:Mrshu.ok@gmail.com
}

\begin{abstract}
The facts and phenomenon that most of senior high school students still encounter or face problems in understanding and answering the questions in reading texts led the researchers to conduct this quasi-experimental research, in line with teaching reading narrative through Inking Your Thinking strategy. This research is aimed at figuring out whether or not there is any significant difference in the tenth grade students' reading comprehension achievements at SMA Negeri 2 Prabumulih among those who are taught by using Inking Your Thinking strategy and those who are not. To collect the data and to meet the objectives, the researchers used two kinds of tests (i.e. pretest and posttest) which were given to 62 students. To analyze the data, the researchers used T-test. The results of the difference analyses on experimental and control groups by using independent sample t-test showed that t-obtained was 4.839 greater than t-table which was 1.671 at the significant level $\mathrm{p}<0.05$ in two tailed testing with $\mathrm{df}=60$. It means that there was significant difference in students' reading comprehension achievements among those who are taught by using Inking Your Thinking strategy and those who are not. In conclusion, Inking Your Thinking strategy can improve students' reading comprehension achievements.
\end{abstract}

Keywords: inking your thinking strategy, reading comprehension, narrative text 


\section{INTRODUCTION}

As the matter of facts, English is still considered as a foreign language taught in EFL classes in many countries. Teaching English as a foreign language means teaching four integrated skills such as listening, speaking, reading, writing). Reading is one of dominat skills that ought to be mastered by students. It can enable them explore their English profeciency, either in written form or in spoken forms. They also can obtain much information and knowledge about anything in relation to English mastery. The more they read, the better they will be. Nunan (2003) stated that reading is such a process in which readers can gain information inside the text related to their prior knowledge to graps gloss (p. 68). It means that reading is like an English skill which has something to do with the information that can improve English ability. In addition, there are many genres of reading texts that a teacher of English can use when teaching reading in the classroom, such as narrative text, descriptive text, procedural text and so on. In this context, narrative text is one kind of text that is familiar used by a teacher of English in teaching reading.

According to Wahidi (2009), narrative is such a reading text which is in line with past events that contains past stories to amuse readers. (p.7). In learning reading, especially narrative texts, many students have problems both in understanding and answering the questions. Since they have limited vocabulary stock, and it makes their reading scores are poor or below school standard. It is relevant with the facts that the researchers obtained from observation and interview with a teacher of English at SMAN 2 Prabumulih, for instances: they were weak at vocabulary mastery and it made them confused with the reading text, they could not answer the questions before translating by looking up the dictionary and they had low reading scores, less than "75" based on minimum passing standard (SKM). In this case, a teacher of English need to apply an effective strategy in teaching reading. One of the effective strategies is that Inking Your Thinking strategy. Donnelly (2007) stated that Inking Your Thinking is a sets divided by three phases, which are (1) before-reading phase, the students would be given stimulus, either concept mapping or question generation; or both of them, to acquire their prior knowledge, (2) duringreading phase, the students would be asked to divide a paper become four parts, they were vocabulary, summary, visualization, and Q \& Do, and (3) afterreading phase, the students would write a short paragraph using their ideas or thinking. So that, the teacher knew if they understand or not with lesson given because it provides information about students' text mastery. (p.11). In brief, this study is hopefully useful for teachers of English to improve their teaching performance in the classroom, so that their students' reading comprehension achievements can be improved.

According to Medina (2012) reading is an interactive text between the author and readers in term of written dialogue and usually used in a daily life. (p. 81). It means that reading such a process of interaction of the readers in understanding the reading text written by 
an author. Moore (2005) stated that the results of teaching process is to having a deep knowledge of the subject matter and a solid understanding of the principles of teaching and learning.(p. 4). In brief, teaching is considered as a process of getting more knowledge in accordance with teaching-learning fundamentals or principles.

Like other experts, Sulaiman (2017) defined teaching as a verbal interaction among the teacher and the students in good learning sequence or atmosphere. (p. 1). It can be inferred that teaching is regarded as learning interaction among teacher and students in terms of either verbal or nonverbal comunication.

In teaching reading the teacher needs to ensure that the students can follow the activity and they understand about the text given, especially for academic purposes, the more they read, the better reading comprehension they will have. Klinger, Vaughn and Boardman (2007), stated that reading comprehension is a multicomponent, highly complex process that involves many interactions between the readers and what they bring to the text (previous knowledge, strategy use) as well as variables related to the text itself (interest in the text, understanding of the test types).(p. 8). It can be summarized that reading comprehension is a process that has many complex components. In this process there would be an interaction between the reader and the results of their thinking from the text after they had read some of the previous texts as well as their understanding of the text.

On the other side, Snow (2002) stated that reading comprehension as the process of simultaneously extracting and constructing meaning through interaction and involvement with written language.(p. 11). It means that comprehension used the words extracting and constructing to emphasize both the importance and insufficiency of the text as a determinant of reading comprehension. Richards and Renandya (2002) stated that reading for comprehension is the primary purpose for reading (though this is sometimes overlooked when the students are asked to read overly difficult text) awareness of main ideas is a text and exploring the organization of a text are essential for good comprehension.(p. 277). In brief, reading comprehension has relationship with the students' ability in developing main ideas into a text organization.

A narrative text tells about past events and has a meaningful story. Zaida (2009) explained that narrative consists of several parts, for instance: orientation which introduces characters and sets the scene (when/where); which tells how the problems resolved, for better or worse.(p. 82). It can be assumed that a narrative paragraph is a story that is created in a constructive format that describes a sequence of fictional or non-fictional events.

Moreover, Gamble and Yates (2002) stated that narrative text has a connection with past events, not an aesthetic invention. (p. 20). In other words, it is a story that is not only concerned with aesthetic factors but also life experience. Zaida (2009) grouped narrative text elements into orientation, setting and resolution. (p. 82). It means that narrative elements have connection with orientation, complication and resolution. To teach narrative text 
effectively, Inking Your Thinking strategy is needed to be applied.

According to Donnelly (2007) Inking Your Thinking is such a teaching reading strategy which helps students improve their skills in decoding the text, learning by heart vocabulary, and understanding it, as well as predicting, analyzing stories, answering questions, and making a summary of the story (p.32). It means that inking your thinking is the strategy for all phases of the reading process and helping to develop students' reading skills such as predicting, analyzing stories, asking questions, constructing, summarizing and self monitoring. Donnelly (2007) further stated that there are three phases of applying Inking Your Thinking Strategy in teaching reading, as follows:

1. Before Reading

Before-reading phase, there are two ways which engage the students in comprehending the text. The first way, the students will be given relevant visual text or printed text consisiting of appropriate vocabulary and knowledge, such as: concept mapping, the second way and the students can be given questions that involve prediction.

2. During Reading

In this case, the students record the unfamiliar or difficult word at the paper or worksheet and then give the synonym or definition of those words, after that they combine of verbs and conjunction, and lastly they demonstrate their complete understanding about the reading text. For Q \& Do activity, the students will be given some questions by the teacher to know the student's comprehending with the reading text, for instance: a. Q (question) How many animals are those in the story?

b. Do (Actions) Please make one paragraph that tell about the story based on your story!

\section{After Reading}

The main strategy during this phase is Reading Response. A Reading Response is an original the studentcreated text. There are three broad categories of 'Reading Response' and they are: Translation, Innovation and Transformation.

\section{METHOD}

In this study, the researchers used 62 students as sample of the research were got from purposive random sampling. Fraenkel, Wallen and Hyun (2012) stated that purposive sampling is different from convenience sampling in that the writer does not simply study who ever is available but rather use their judgment to select a sample that they believe, based on prior information, will provide the data they need.(p. 101). In this study, the researchers got Class X MIPA 1 and $\mathrm{X}$ MIPA 5, based on observation and interview with the teacher of English and supported by the evidence that the students' reading scores were less than "75" based on Minimum Passing Standard (SKM). To be detailed, Table 1 presents sample of the study. 
Table 1. Sample of the Research

\begin{tabular}{|c|c|c|c|}
\hline No & Class & Students & Group \\
\hline 1 & X.MIPA.5 & 31 & Control \\
\hline 2 & X.MIPA.1 & 31 & Experimental \\
\hline
\end{tabular}

Table 1 describes 62 students as samples of the study who were grouped as a control class (X MIPA 5 of 31 participants) and experimental class (X MIPA 1 of 31 participants). In collecting the data, the researchers used test in terms of pretest and posttest as an instrument of the study. Pretest was given to students before treatment to know reading achievements. It was given after tryout. While, Posttest was given after pretest and it was to know their achievements. In addition, the researchers used quasiexperimental design, the pretest-posttest nonequivalent groups design use as a research procedure. Cohen, Lawrence and Keith (2007) formulated the design, as follows:

Experimental Control (p.283)
Where :

.....: Dash line indicate that the experimental and control group have not been equate by randomization.

$\mathrm{O}_{1} \quad$ : Pretest in experimental group

$\mathrm{O}_{2} \quad$ : Posttest in experimental group

$\mathrm{X} \quad$ : Treatment in experimental group

$\mathrm{O}_{3} \quad$ : Pretest in control group

$\mathrm{O}_{4} \quad$ : Posttest in control group

\section{FINDINGS AND DISCUSSION} The Result of Students' Pretest Score in Control Group

There were 31 students participated during pretest. To be vivid, Table 2 illustrates the frequency of Pretest in Ccontrol Group.

Table 2. The Frequency of Pretest in Control Group

Frequency Percent Valid Percent Cumulative Percent

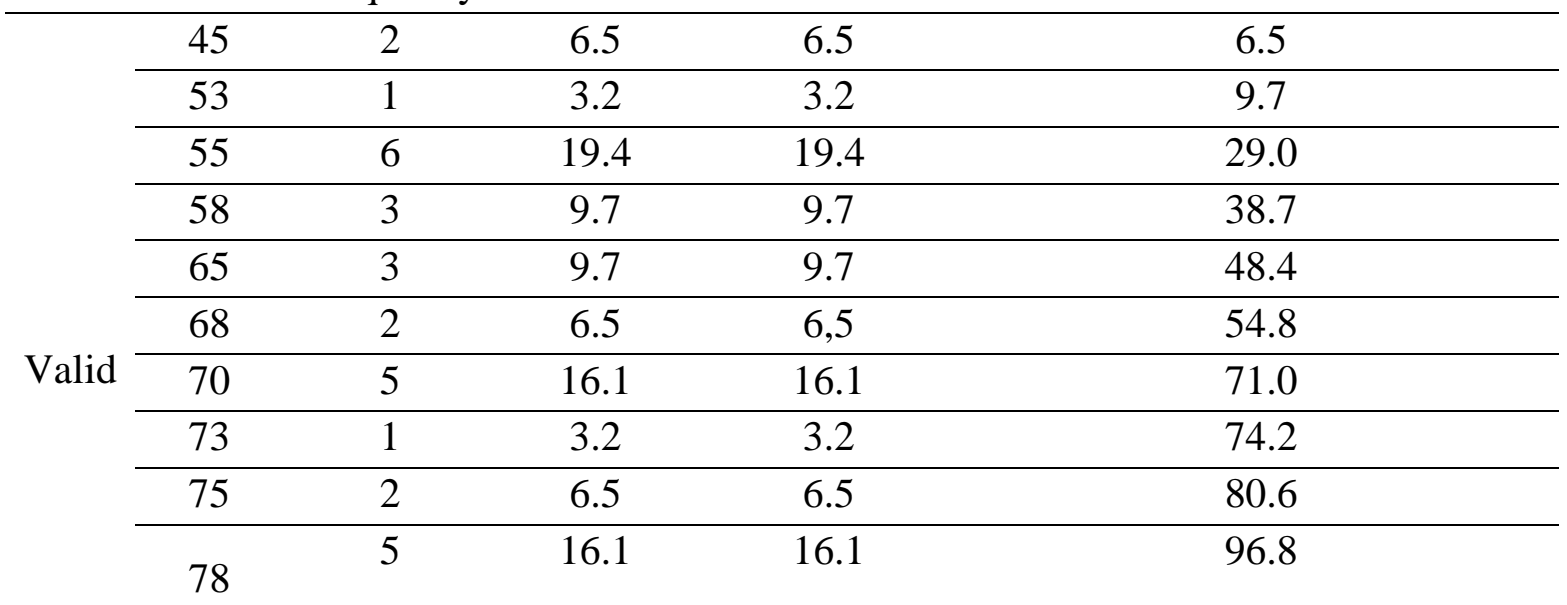




\begin{tabular}{ccccc}
85 & 1 & 3.2 & 3.2 & 100.0 \\
\hline Total & 31 & 100.0 & 100.0 &
\end{tabular}

Table 2 illustrated the results of pretest in control group of the highest score was 85 and the lowest score was 45. There was one student $(3.2 \%)$ who got 85 ,which was considered as the highest score, five students $(16.1 \%)$ who got 78 , two students $(6.5 \%)$ who got 75 , one student $(3.2 \%)$ who got 73 , five students (16.1\%) who got 70 , two students (6.5\%) who got 68, three students $(9.7 \%)$ who got 65 , three students $(9.7 \%)$ who got 58 , six students (19.4\%) who got 55 , one student $(3.2 \%)$ who got 53, and two students $(6.5 \%)$ who got 45, which was considered as the lowest score. In addition, Table 3 presents the frequency of posttest in control group.

Table 3. The Frequency of Posttest in Control Group

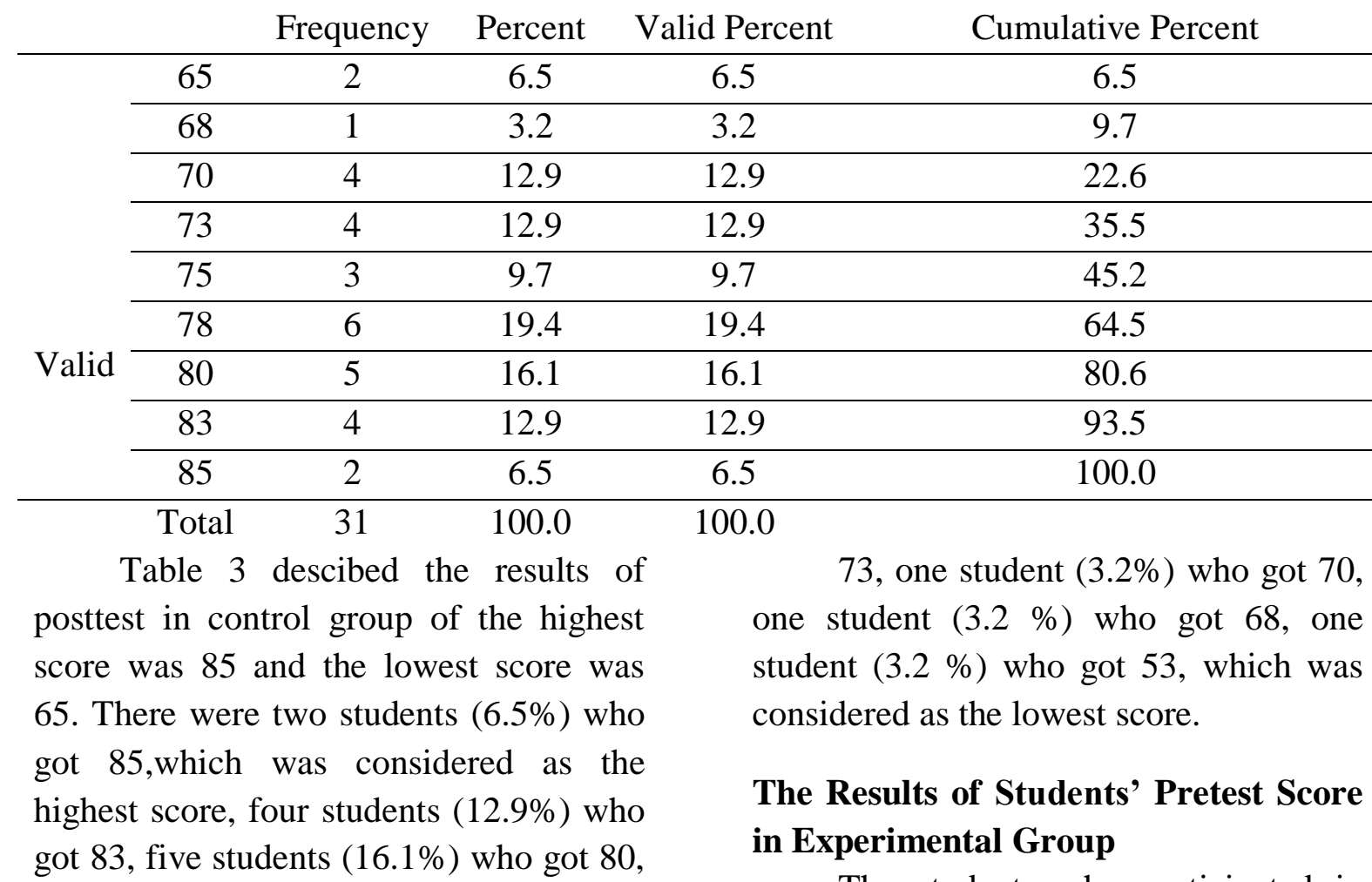
six students (19.4\%) who got78, three students $(9.7 \%)$ who got 75 , five students (16.1) who got 80 , one student $(3.2 \%)$ who got 78 , two students $(6.5 \%)$ who got

The students who participated in the pretest were 31 students. The pretest was given to the students before the treatments. In addition, Table 4 presents the frequency of pretest in experimental group 
Table 4. The Frequency of Pretest in Experimental Group

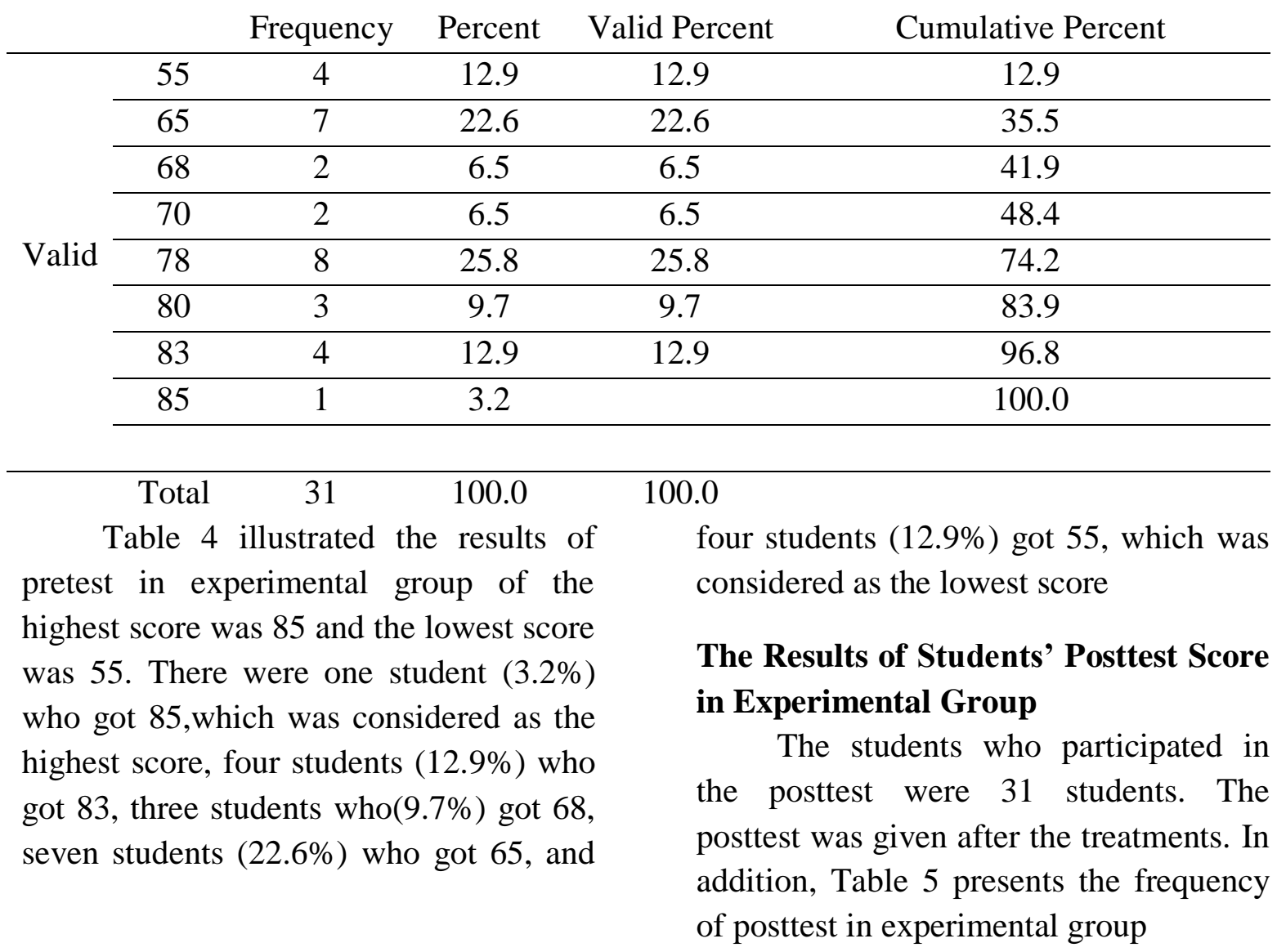

Table 5. The Frequency of Posttest in Experimental Group

\begin{tabular}{|c|c|c|c|c|c|}
\hline & & Frequency & Percent & Valid Percent & Cumulative Percent \\
\hline & 63 & 1 & 3.2 & 3.2 & 3.2 \\
\hline & 65 & 1 & 3.2 & 3.2 & 6.5 \\
\hline & 68 & 1 & 3.2 & 3.2 & 9.7 \\
\hline & 70 & 1 & 3.2 & 3.2 & 12.9 \\
\hline & 75 & 1 & 3.2 & 3.2 & 16.1 \\
\hline & 78 & 2 & 6.5 & 6.5 & 22.6 \\
\hline & 80 & 1 & 3.2 & 3.2 & 25.8 \\
\hline Valid & 83 & 1 & 3.2 & 3.2 & 29.0 \\
\hline & 85 & 5 & 16.1 & 16.1 & 45.2 \\
\hline & 88 & 4 & 12.9 & 12.9 & 58.1 \\
\hline & 90 & 6 & 19.4 & 19.4 & 77.4 \\
\hline & 95 & 6 & 19.4 & 19.4 & 96.8 \\
\hline & 98 & 1 & 3.2 & 3.2 & 100.0 \\
\hline & Total & 31 & 100.0 & 100.0 & \\
\hline
\end{tabular}

Table 5 described the results of score was 98 and the lowest score was posttest experimental group of the highest

63. There wereone student $(3.2 \%)$ who 
got 98, which was considered as the highest score, six students (19.4\%) who got 95, six students (19.4\%) who got 90, four students $(12.9 \%)$ who got 88 , five students $(16.1 \%)$ who got 85 , one student (3.2\%) who got 83 , one student $(3.2 \%)$ got 80 . two students $(6.5 \%)$ who got 78 , one student $(3.2 \%)$ who got 75 , one student $(3.2 \%)$ who got 70 , one student (3.2\%) who got 68 , one student $(3.2 \%)$ who got 65 , and one student $(3.2 \%)$ who got 63 , which was considered as the lowest score.

The Differences between Pretest and Posttest Scores in Experimental Group To compare pretest and posttest, the writer used Paired Sample t-test through SPSS 21.0 Program. Additionally, Table 6 presents the result of the paired sample t-test.

Table 6. Paired Samples Statistics Pretest and Posttest Experimental Group

Paired Samples Statistics

\begin{tabular}{llllcc}
\hline & & Mean & N & Std. Deviation & Std. Error Mean \\
\hline \multirow{2}{*}{ Pair 1 } & Pretest_Exp & 72.00 & 31 & 9.438 & 1.695 \\
\cline { 2 - 6 } & Posttest_Exp & 85.32 & 31 & 9.268 & 1.665 \\
\hline
\end{tabular}

Table 6 illustrated pretest score of (9.268) and standard error mean of the experimental group of the mean score was (72.00), the standard deviation was (9.438) and standard error mean of pretest was (1.695). While, posttest score ofthe experimental group, the mean was (85.32) the standard deviation was

Table 7. The Result of Paired Sample t-Test Pretest and Posttest in Experimental Group Paired Samples Test

\begin{tabular}{|c|c|c|c|c|c|c|c|c|}
\hline & \multicolumn{5}{|c|}{ Paired Differences } & \multirow{3}{*}{\multicolumn{2}{|c|}{ df }} & \multirow[t]{3}{*}{ Sig. (2-tailed) } \\
\hline & \multirow{2}{*}{\multicolumn{2}{|c|}{$\begin{array}{c}\text { Mean } \begin{array}{c}\text { Std. } \\
\text { Deviatio } \\
n\end{array} \\
\end{array}$}} & \multirow[t]{2}{*}{$\begin{array}{l}\text { Std. } \\
\text { Error } \\
\text { Mean }\end{array}$} & $\begin{array}{r}95 \% \mathrm{Co} \\
\text { Interva } \\
\text { Diffe }\end{array}$ & $\begin{array}{l}\text { afidence } \\
\text { lof the } \\
\text { rence }\end{array}$ & & & \\
\hline & & & & Lower & Upper & & & \\
\hline $\begin{array}{cl}\text { Pair } & \text { Pretest_Exp - } \\
1 & \text { Posttest_Exp }\end{array}$ & $\begin{array}{c}- \\
13.32 \\
3\end{array}$ & 12.327 & 2.214 & -17.844 & -8.801 & $\begin{array}{c}- \\
6.017\end{array}$ & 30 & .000 \\
\hline
\end{tabular}

Table 7 described the result of Paired t-test showed the value of $t$ obtained was -6.017 . the critical value of $\mathrm{t}$-table was 1.673 at the significant level $\mathrm{p}$ $<0.5$ for 2-tailed and degree of freedom (df) was 30, Therefore t-obtained was greater than -table, so that $\mathrm{H}_{\mathrm{o}}$ (Null Hypothesis) was rejected and $\mathrm{H}_{\mathrm{a}}$ (Alternative Hypothesis) was accepted, because the differences between the experimental group scores and control group there was significant differences 
between the students' score at the Tenth Grade Students who were taught through

The Differences between Pretest and Posttest of Control Group

To compare pretest and posttest, the writer used paired sample t-test in SPSS
Inking Your Thinking Strategy of the students' scores of those who were not.

Program. In addition, Table 8 presents the result of the paired sample t-test statistics.

Table 8. Paired Samples t-test Statistics Pretest and Posttest in Control Group Paired Samples Statistics

\begin{tabular}{llllcc}
\hline & & Mean & N & \multicolumn{2}{c}{ Std. Deviation Std. Error Mean } \\
\hline \multirow{2}{*}{ Pair 1 } & Pretest_Control & 65.35 & 31 & 10.550 & 1.895 \\
\cline { 2 - 6 } & Posttest_Control & 76.29 & 31 & 5.623 & 1.010
\end{tabular}

Table 8 illustrated the pretest score standard deviation was (5.623) and in control group of the mean was (65.35), standard error mean of posttest (1.161). the standard deviation was (10.550) and Additionally, Table 9 presents the result standard error mean of pretest was of paired sample t-test pretest and posttest (1.895). While, the posttest score in in control group. control group, the mean was (76.29) the

Table 9. The Result of Paired Sample t-Test Pretest and Posttest in Control group

Paired Samples Test

\begin{tabular}{|c|c|c|c|c|c|c|}
\hline & \multicolumn{3}{|c|}{ Paired Differences } & \multirow[t]{3}{*}{$\mathrm{t}$} & \multirow[t]{3}{*}{ Df } & \multirow{3}{*}{$\begin{array}{l}\text { Sig. (2- } \\
\text { tailed) }\end{array}$} \\
\hline & \multirow[t]{2}{*}{ Mean } & \multirow[t]{2}{*}{$\begin{array}{l}\text { Std. } \\
\text { Deviat } \\
\text { ion }\end{array}$} & $\begin{array}{c}95 \% \text { Confidence } \\
\text { Interval of the } \\
\text { Difference }\end{array}$ & & & \\
\hline & & & Lower Upper & & & \\
\hline $\begin{array}{c}\text { Pair Pretest_Control - } \\
1 \text { Posttest_Control }\end{array}$ & $\begin{array}{c}- \\
10.93 \\
5\end{array}$ & $12.391 \quad 2.225$ & $-15.480 \quad-6.391$ & $\begin{array}{c}- \\
4.914\end{array}$ & 30 & .000 \\
\hline
\end{tabular}

Table 9 described the result of pretest and posttest in control group could be seen in Table 4.20.The result of the paired sample t-test showed that the value of t-obtained was -4.914 , at significant level>0.05 for two tailed test and degree of freedom was 30 .

\section{The Comparison of Posttest Experimental Group and Control Group by Using Independent Sample t- Test}

Based on the results of the test, this study was to find out the comparison of result score between experimental group and control group. The comparison of scores posttest in experimental and control groups were analyzed by using Independent Sample t-test. To be clear, 
Table 10 illustrates the results of the group and control group by using comparison of posttest experimental

Table 10. Independent Samples Test Independent Samples Test

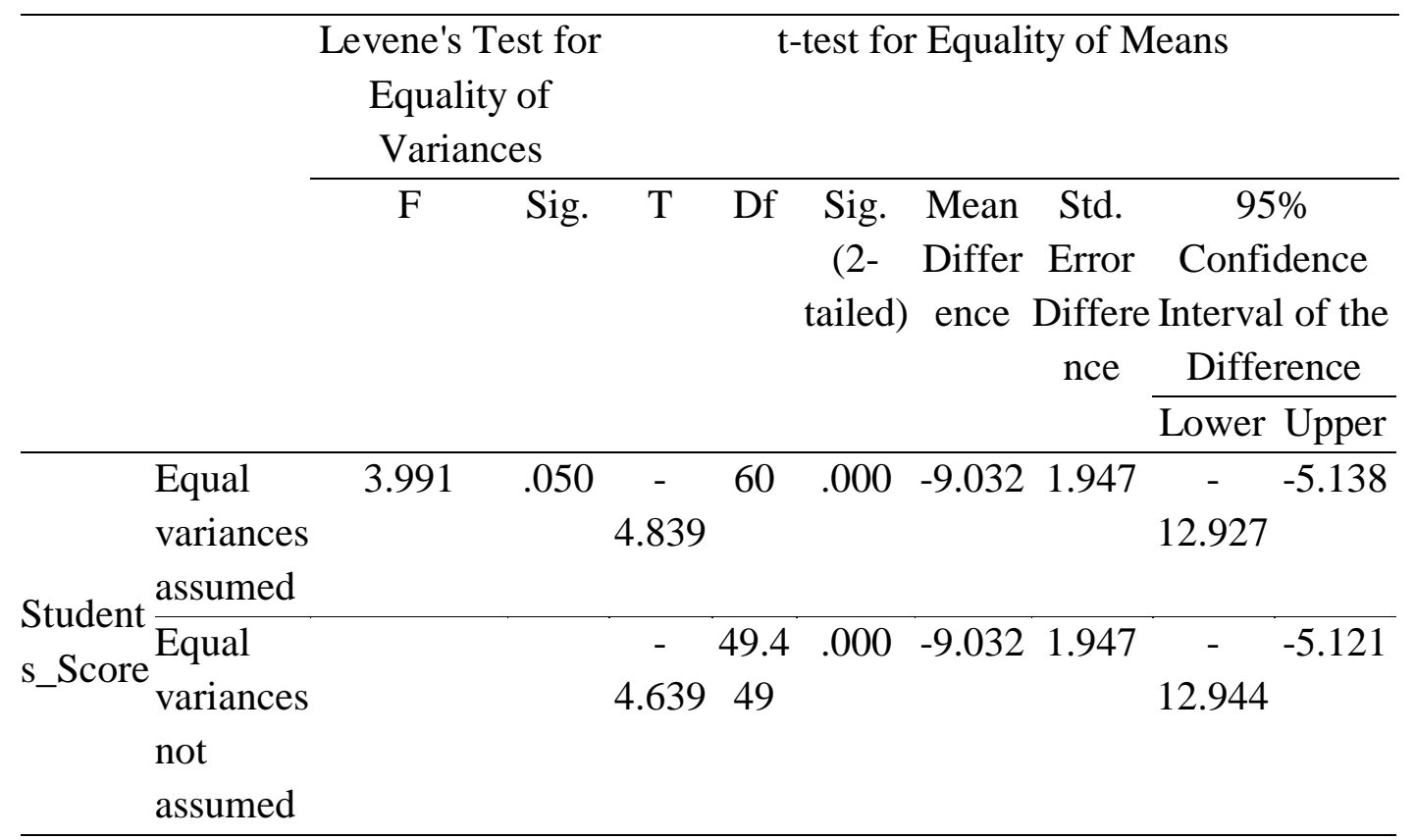

Table 10 illustrated the result of the independent sample t-test, showed the value of t-obtained was 4.839 at the significant level of $p<0.05(5 \%)$ in 2 tailed testing degree of freedom (df) was 60 , and the critical value of t-table was 1.671. Since the value of $t$-obtained was greater than the critical value of t-table. So, that the null hypothesis $\left(\mathrm{H}_{\mathrm{o}}\right)$ was rejected and the Alternative hypothesis $\left(\mathrm{H}_{\mathrm{a}}\right)$ was accepted.

Based on the calculation by using SPSS 21.0 program, the mean in the experimental group of pretest score was 72.00 while the mean of posttest score was 85.32. The result of mean from pretest and posttest in experimental group depicted that there was significant differences between the students score pretest and posttest score. The mean in control group of pretest score was 65.35 , and the mean of posttest score was 76.29. In addition, the result of mean from pretest and posttest in the control group revealled that there was the differences between the students pretest score and posttest score but not significance as in the experimental group.

Based on the statistical analysis of independent sample t-test, the result of students' scores in experimental group and control groups that was the value of t-obtained 4.839 were greater than t-table (1.671). It could be concluded that $\mathrm{H}_{\mathrm{o}}$ (Null Hypothesis) was rejected and $\mathrm{H}_{\mathrm{a}}$ (Alternative Hypothesis) was accepted.

In the process of learning reading comprehension, students faced many problems that affected students in learning reading comprehension. Thus, 
the result of pretest and posttest which was too significant. From the data obtained from the research, the researchers found that there were several factors. Those factors were firstly, the students had limited vocabulary. In the result, students could not understand the reading text, they could not answer the questions directly, since students looked up the dictionary before translating, and they had low reading score which was less than "75" based on minimum passing standard (SKM). Secondly, the writer observed that English teachers in that school did not provide particular techniques in teaching reading. They tend to use the conventional method in the class. Thus, the students did not enjoy learning reading comprehension.

The last factor was that the school did not provide adequate facilities to support teachers and students in learning English in the class. For instance, the school only had one infocus, thus the teacher and students used the device by turns with another class. By looking at those three factors, the school and teachers should concern to facilitate the students in learning English particularly learning reading comprehension.

\section{CONCLUSION}

Based on the findings and discussion stated, it could be drawn some conclusions. Firstly, Inking Your Thinking strategy was an effective way to develop students' ability in reading comprehension. Secondly, the students found that Inking Your Thinking strategy was interesting, which make them able to understand the text easily than the students who are not using Inking Your Thinkingstrategy. Thirdly, the measure of the students' reading comprehension in the experimantal group was greater than in the control group. Fourthly, the students' English ability was improved by applying the Inking Your Thinking strategy in reading comprehension. Fifthly, based on the Independent Sample t-test, the result of t-obtained was 4.839 greater than 1.671 as its critical value of t-table. It means that teaching reading comprehension through Inking Your Thinking strategy was significant difference on the Tenth Grade Students' reading comprehension achievement taught through Inking Your Thinking strategy.

\section{REFERENCES}

Cohen, L., Lawrence, M., \& Keith, M. (2007). Research method in education. London: Routledge.

Donnelly, P. (2007). Inking Your Thinking Strategy: The Ultimate Meaning Making Strategy. Journal of Literacy Learning, 15(1), 3

Fraenkel, J. R., Wallen, N. E., \& Hyun, H. (2012). How to design and evaluate research in education. San Francisco, McGraw-Hill Higher Education.

Gamble, N., \& Yates, S. (2002). Exploring childrens's liturature: Teaching tanguage and reading of fiction. New York, NY: SAGE Publication Inc.

Klinger, J. K. Vaughn, S., \& Boardman, A. (2007). Teaching reading comprehension to students with learning difficulties. New York, NY: Guildford Press.

Medina, S. L. (2012). Effect of Strategy Instruction in an EFL Reading Comprehension Course: A Case Study. Profile Journal, 14(1),79-89. 
Moore, D. K. (2005). Effective instructional strategies: from theory to practice. New Delhi, India: Sage Publication, Inc.

Nunan, D. (2003). Second language teaching \& learning. New York, NY: Mc Graw Hill.

Richards, J. C., \& Renandya.W. A. (2002). Methodology in language teaching: An antholohy of current practice. New York, NY: Cambridge University Press.

Snow, C. (2002). Reading for understanding: toward an $R \& D$ program in reading comprehension. Santa Monica, CA: RAND.

Sulaiman, MGS. (2017). Teach the Students not the books: A handbook of TEFL. Noerfikri: Palembang.

Wahidi, R. (2009). Genre of the Text. Retrieved January 3, 2018 from http://racmatwahidi.wordpress.com.

Zaida, N. (2009). Mandiri practice your English competence. Jakarta: Erlangga. 